\title{
Psychiatric Training: The Culture and Its Contradictions by T.M. Luhrmann
}

Carolyn Myers M.D.

Follow this and additional works at: https://jdc.jefferson.edu/jeffjpsychiatry

Part of the Psychiatry Commons

Let us know how access to this document benefits you

\section{Recommended Citation}

Myers, Carolyn M.D. (2001) "Psychiatric Training: The Culture and Its Contradictions by T.M. Luhrmann," Jefferson Journal of Psychiatry. Vol. 16 : Iss. 1 , Article 9.

DOI: https://doi.org/10.29046/JJP.016.1.009

Available at: https://jdc.jefferson.edu/jeffjpsychiatry/vol16/iss1/9

This Article is brought to you for free and open access by the Jefferson Digital Commons. The Jefferson Digital Commons is a service of Thomas Jefferson University's Center for Teaching and Learning (CTL). The Commons is a showcase for Jefferson books and journals, peer-reviewed scholarly publications, unique historical collections from the University archives, and teaching tools. The Jefferson Digital Commons allows researchers and interested readers anywhere in the world to learn about and keep up to date with Jefferson scholarship. This article has been accepted for inclusion in Jefferson Journal of Psychiatry by an authorized administrator of the Jefferson Digital Commons. For more information, please contact: JeffersonDigitalCommons@jefferson.edu. 


\title{
Book Review
}

\section{Psychiatric Training: The Culture and Its Contradictions}

\author{
Of Two Minds: \\ The Growing Disorder in American Psychiatry \\ by T.M. Luhrmann \\ 328 pages, $\$ 26.95$, ISBN 0-679-42191-2 \\ New York: Alfred A. Knopf, 2000
}

Carolyn Myers, M.D.

I was fortunate to stumble upon this book by accident while I was browsing at Barnes and Noble about two weeks before the start of my first year of residency, so naturally my curiosity was piqued. In the well researched book, T.M. Luhrmann, an anthropologist, explores many aspects of a psychiatry resident's training from a unique point of view. She describes her first experiences with psychiatric training as "disturbing and perplexing but also deeply intriguing." It is clear that it is not the patients that she finds disturbing, but rather the training itself and the effect that various influences, especially managed care, have had on this training and subsequent patient care practices.

I should note that this book is not written with psychiatrists as the sole intended audience. It is written from a point of view that anyone with an interest in mental health care would find readable, easy to understand and interesting.

The author begins by explaining the difference between the psychodynamic perspective of mental illness versus a biomedical or, as she describes, scientific perspective. With these two very different approaches to psychiatric illness in mind she follows young psychiatrists through their training and demonstrates how they are taught these two main areas of skill. While she obviously sees the merit of both models of mental illness, she clearly feels that most psychiatric treatment is conforming more and more to a biomedical perspective at the expense of what the patient might gain from a more psychodynamic approach to their illness.

She cites many studies that speak to the effectiveness of psychotherapy in general. Two I found particularly interesting showed that psychotherapy is even capable of altering the brain's metabolic activity in a similar fashion to medication $(1,2)$. She also makes a good case for the cost effectiveness of psychotherapy noting 
that "a year of weekly outpatient psychotherapy saves money if it prevents one six day admission."

In addition, she describes the changes that managed care has brought to psychiatry, lamenting that psychotherapy is often eliminated from a treatment plan in response to managed care policies. She realistically notes that "the dilemma for psychotherapists in the age of managed care is how to maintain medical funding for a 'procedure' that they know to be useful but that lends itself poorly to the type of rigorous study that is increasingly necessary in the current health care environment." While recognizing that managed care policies are not always detrimental, for example some patients may actually benefit from a shorter hospital stay, Luhrmann recognizes that the psychotherapeutic way of thinking does not easily fit into time constraints imposed by managed care companies.

She concludes with a philosophical chapter that looks at the responsibility of society to the mentally ill. The reader is challenged to see a patient not simply as a diagnosis or a diseased brain, but rather as a complex person often capable of responsibility and productivity, of "full personhood." When psychotherapy is eliminated from treatment, the author fears, we will be depriving patients both in a practical as well as a moral sense.

I thoroughly enjoyed reading this book. It was very inspiring to me as I suppose I am still somewhat idealistic when I consider the type of psychiatrist I hope to become. I believe reading this book will motivate me to try to understand my patients and their actions on a much deeper level. I hope that I will also view my patients as people whose lives are filled with possibilities despite the limitations that their illness might impose. I recommend this book highly to my fellow residents and our teachers. I also think it could be helpful to patients and their families in certain circumstances. In an ideal world I would also have the managed care policy makers read it and heed many of the author's warnings.

\section{REFERENCES}

1. Schwartz JM, Stoessel PW, Baxter LR, et al: Systematic changes in cerebral glucose metabolic rate after successful behavior Modification Treatment of Obsessive-compulsive disorder. Arch Gen Psychiatry 1996; 53: 109-113.

2. Baxter L, Schwartz JM, Bergman KS, et al: Caudate glucose metabolic rate changes with both drug and behavioral therapy for obsessive-compulsive disorder. Arch Gen Psychiatry 1992; 49: 681-689. 